\title{
Biotoxicity of CdS/CdSe Core-Shell Nano-Structures
}

\author{
Sreenu Bhanoth1, Anuraj S. Kshirsagar1, Pawan K. Khanna1*, Aakriti Tyagi2, \\ Anita K. Verma ${ }^{2 *}$ \\ ${ }^{1}$ Nanochemistry R \& D Lab, Department of Applied Chemistry, Defence Institute of Advanced Technology \\ (DIAT), Ministry of Defence, Government of India, Girinagar, Pune-411 021, India \\ ${ }^{2}$ Nano Bio-Tech Lab, Department of Zoology, Kirorimal College, University of Delhi, Delhi, India \\ Email: "pawankhanna2002@yahoo.co.in, "khannap@diat.ac.in, "akamra23@hotmail.com
}

Received 3 August 2015; accepted 1 February 2016; published 4 February 2016

Copyright (C) 2016 by authors and Scientific Research Publishing Inc.

This work is licensed under the Creative Commons Attribution International License (CC BY).

http://creativecommons.org/licenses/by/4.0/

\section{(c) (i) Open Access}

\begin{abstract}
The cytotoxicity of hydrophobic QDs CdS/CdSe was tested assigning MTT assay on Human Embryonic Kidney cells (HEK-293), breast cancer cells (MCF-7) and Enrichlish Ascitices Cells (EAC). Approximately 65\% bio-toxicity was observed in MCF-7 for the core-shell QDs. These QDs may also find effective applications in other optoelectronic devices. CdS/CdSe core-shell hetrostructure quantum dots (QDs) were generated by chemical reaction between the respective chalcogens and cadmium metal salt. Sulphur powder was utilized for CdS core preparation while selenium was extracted from an organoselenium compound to impart CdSe shell layer at a temperature between $150^{\circ} \mathrm{C}-200^{\circ} \mathrm{C}$. So-prepared core-shell QDs showed good optical properties. The particle size was found to be in the range of $3-4 \mathrm{~nm}$ with spherical morphology and cubic crystal structure.
\end{abstract}

\section{Keywords}

Quantum Dots, Metal Chalcogenides, Bio-Toxicity, Cell Lines

\section{Introduction}

Amongst II-VI QDs, CdS, ZnSe, CdSe and core-shell type e.g. ZnSe/CdS, CdS/CdSe etc. are documented to be important for photonics and biomedical applications because of their inorganic nature which offers good environmental and photostability as well as chemical inertness. Such QDs are useful because of their tunable optical properties in the entire visible light spectrum. Because of their suitability for biological as well as for photonics

${ }^{*}$ Corresponding authors. 
application, synthesis of tailor made particles with amphiphilic (hydrophoibic as well as hydrophilic) surfaces are often advantageous [1]-[4]. Application of QDs in bio-medicine is expected to bring great advantage in diagnosis and treatment of disease. Potential areas that may get advantage by utility of quantum dots including drug delivery, clinical diagnostics, diet industry and improved biocompatible materials. Semiconductor QDs are future tools that can offer better viability and control targets. In pursuit of the use of QDs, researchers have maintained importance of the synthesis, dispersion, bio-solubilisation and bio-conjugation of fluorescent QD with a core-shell type of nano-structures. A nano-structure with core composed of CdS or CdSe material and shell of a semiconductor material helps to stabilize the core which further helps to improve optical properties as well as bioavailability of the material. In last few decades good efforts were taken by various research groups and scientists for the synthesis of various types of good quality QDs (including core-shell nano-structures) in terms of their dispersion in organic as well as aqueous medium and making them typically hydrophilic or hydrophobic. Cadmium chalcogenide QDs are very useful in the variety of in vitro and in vivo applications because of their versatile surface chemistry and superior optical properties [5]. The application of such QDs in bioimaging attracted attention of the researchers because of good simultaneous coupling with biological molecules or ligands [6]. Fluorescence efficiency can be optimized via inorganic or organic coatings on QDs because of dangling bonds. Water dispersibility and bioactivity of QDs can be enhanced by coatings of biocompatible materials or polymer. For utility of QDs in biology functionalization is required to recognize molecules such as proteins, peptides and nucleic acids, forming bio-conjugates [7]. It has been documented that size-tunable CdSe QDs have great potential in diagnosis of cancerous cells. However, pharmacokinetic and toxicology studies require further detailed understanding and analysis [8]. Additionally, the surfactants such as long chain carboxylic acids, alkyl or aryl amines and low molecular weight polymers normally are employed to improve the quality of quantum dots for a variety of applications. Another option to alter the surface is by coating of same group QDs as a shell upon inorganic core called core-shell structures such as CdSe/CdS [3], CdSe/ZnS [4], CdSe/CdTe [9], $\mathrm{CdSe} / \mathrm{ZnSe}$ [10], CdTe/CdSe [11]. We have recently reported synthesis and characterization of $\mathrm{ZnSe} / \mathrm{CdSe}$ coreshell quantum dots and its relation with size and optical properties [12].

Size, surface chemistry, charge and monodispersity are important properties required to facilitate the biological internalization of QDs. Cadmium and selenium are essentially toxic to cells and living organisms leading to apprehension over their potential toxicity for in vivo applications. Several researchers in the past have demonstrated cytotoxic studies of quantum dots e.g. Derfus et al. [13] studied the cytotoxicity of CdSe QDs and pointed out that without presence of coating, the cytotoxicity of CdSe core can be correlated with the liberation of free $\mathrm{Cd}^{2+}$ ions due to deterioration of QDs lattice. According to them the liver is the primary site of acute injury in vivo caused by cadmium ions even when the concentration of $\mathrm{Cd}^{2+}$ ion is reduced to minimum level. It has been opined that quantum confinement effect could further lead to cytotoxicity because QDs within certain diameters may be of similar size to certain cellular components and proteins bypassing natural mechanical barriers, thus leading to adverse tissue reactions [14]. Similarly, highly luminescent QDs such as core/shell $\mathrm{CdSe} / \mathrm{ZnS}$ and core/shell/shell CdSe/ZnS/TEOS type were developed by Dabbousi et al. [15] and Selvan et al. [16] and have been tested for their biototoxicity. Chenbo et al. [17] [18] studied change in cellular biomechanics with exposer of carbon nanotubes and cytotoxicity effect of MWCNT (Multiwall carbon nanotubes) on human lung epithelial cells. Similarly, Seigrist et al. [19] reported genotoxicity caused by MWCNT. Zhang et al. [20] studied effect of nitrogen doped carbon QDs on living (Hela) cell and as selective probe for Fe. In the current work we assigned MTT assay on MCF-7, HEK-293 and EAC cell lines and evaluated internalization as well as cellular uptake induced biotoxicity by use of CdS/CdSe QDs.

Previously our group reported synthesis of $\mathrm{CdSe}$, ZnSe and $\mathrm{ZnSe} / \mathrm{CdSe}$ QDs by using cyclohexeno1,2,3-selenadiazole where in it was shown that cyclohexeno-1,2,3-slenadiazole can be used effectively for synthesis of various types of chalcogenide based QDs including core-shell nano-structures [12]. In order to use QDs in various fields of optoelectronic, biological and medical fields, the cellular uptake, internalization and toxicity mechanism of QDs need to be evaluated. As part of our on-going studies, we herein present a simpler method for synthesis of $\mathrm{CdS} / \mathrm{CdSe}$ core-shell and its cytotoxic studies. This paper describes a synthetic method that avoids use of toxic TOPSe for inverted core-shell structures CdS/CdSe. Well known organometallic selenium-N heterocyclic compound cyclohexeno-1,2,3-selenadiazole has been exploited as selenium precursor along with cadmium acetate as cadmium precursor and oleic acid as capping agent. The reaction was performed at much lower reaction temperature than those documented in the literature. Additionally, internalization of cellular in- 
duced biotoxicity assigning MTT assay on anti cancer HEK-293, MCF-7 and EAC cell lines was studied.

\section{Materials and Methods}

\subsection{Chemicals}

Cadmium acetate dihydrate, 1,2,3-selenadiazole [21], sulphur (99.9\%), Diphenyl ether (98\%), Oleic acid (98\%), paraformaldehyde, n-hexane, (3-(4,5-dimethylthiazol-2-yl)-2,5-diphenyltetrazolium bromide, dimethylsulfoxide (DMSO) and methanol were purchased from Aldrich and used without further purification. UV-Visible spectrum was recorded at room temperature using analytik jena SPECORD@210 PLUS spectrophotometer. Similarly, photoluminescence (PL) spectrum was taken on Cary-Eclipse Fluorescence spectrophotometer (Agilent Technology) at an excitation wave length of $350 \mathrm{~nm}$. X-ray diffraction (XRD) measurement was done with a Bruker D8 advance diffractometer with $\mathrm{Cu}$-Ka radiation (1.5405 $\AA$ ). Transmission electron microscopy (TEM) was done on FEI Tecnai $\mathrm{G} 2$ with $30 \mathrm{KV}$.

\subsection{Preparation of Hydrophobic Core-Shell Quantum Dots}

Core CdS hetero nano-structures were initially prepared via customized literature method developed by our group [12]. $\mathrm{Cd}(\mathrm{Ac})_{2}$ or $\mathrm{CdO}$ was dissolved in a mixture of oleic acid $(\mathrm{OA})$ and diphenyl ether by maintaining temperature between $100^{\circ} \mathrm{C}-150^{\circ} \mathrm{C}$. Pre-dissolved sulphur in diphenyl ether was injected in to the reaction mixture in the temperature range of $150^{\circ} \mathrm{C}-200^{\circ} \mathrm{C}$ and stirred for some time at the same temperature. For over growth of CdSe shell cyclohexeno-1,2,3-selenadiazole and Cd-precursor were added in the same mixture and the reaction was continued for 2 - 3 hrs. CdS/CdSe QDs were precipitated by addition of methanol and collected via centrifugation followed by simultaneous washings with ethanol and finally dried in vacuum oven at room temperature.

\subsection{Cell Culture and Cytotoxicity Studies of Quantum Dots}

The in vitro evaluation was done on Human Embryonic Kidney cell line HEK-293 and Human breast adenocarcinoma MCF-7 cell line (American Type Culture Collection, Rockville, MD) [22]. Confluent flasks were subcultured and maintained at $36^{\circ} \mathrm{C}$ in Dulbecco's modified Eagle's medium (Sigma, St. Louis, MO) supplemented with $10 \%$ fatal calf serum (Himedia), and antibiotic containing $50 \mathrm{U} / \mathrm{mL}$ of penicillin (Sigma) and $50 \mathrm{mg} / \mathrm{mL}$ of streptomycin (Sigma, USA) under a humidified atmosphere $\left(5 \% \mathrm{CO}_{2}\right)$. Briefly, $5 \times 10^{3}$ cells/well of HEK-293, MCF-7 and EAC cells were plated in 96-well microtiter plates. CdS/CdSe QDs were then added to the cells at defined concentrations $(10 \mu \mathrm{g} / \mathrm{mL}, 5 \mu \mathrm{g} / \mathrm{ml}$ and $2.5 \mu \mathrm{g} \cdot \mu \mathrm{g} / \mathrm{mL})$ and incubated for 24 hours and 48 hours. After incubation, $20 \mu \mathrm{l}$ of MTT (3-(4,5-dimethylthiazol-2-yl)-2,5-diphenyltetrazolium bromide; $(5 \mathrm{mg} / \mathrm{mL})$ was then added per well and the plate was incubated for four hours in an incubator. After incubation, the media was discarded carefully without disturbing the formazan crystals in the wells and $120 \mu \mathrm{l}$ of dimethyl sulfoxide was added to solubilize the formazan crystals formed and reading were taken in a (Synergy HT, Biotek, USA) using a $540 \mathrm{~nm}$ filter [23]. All measurements were done in triplicates. Percentage viability of the cells was calculated as the ratio of mean absorbance of triplicate readings with respect to mean absorbance of control wells.

Cell viability $=\left(\mathrm{I}_{\text {control }}-\mathrm{I}_{\text {sample }} / \mathrm{I}_{\text {control }}\right) \times 100$

\subsection{Cellular Uptake}

For understanding the internalization of nanoparticles cellular uptake was assessed in a fluorescence microscope as per our published protocols [24]. Briefly, MCF-7, HEK-293 and EAC cells were cultured on coverslips till $90 \%$ confluence was attained. The cells were further incubated with $10 \mu \mathrm{g} / \mathrm{ml}$ of CdS/CdSe QDs. The cells were fixed with $4 \%$ paraformaldehyde and visualized in a fluorescence microscope (Eclips 90i, Nikon) at Mag. 20×.

\section{Results and Discussion}

Growth of a CdSe shell around the core CdS resulted in an increase in particle diameter which was monitored via absorption spectroscopy. As shell grows around CdS core both absorption and emission wavelength show systematic red-shifts i.e. shifts towards the longer wavelength, indicative of formation of larger particle possibly due to clustering. This red-shift can be correlated with decrease in band gap of CdSe due to the formation of $\mathrm{CdS} / \mathrm{CdSe}$ core-shell. Such observations are quite handy in termination of chemical reaction during the synthesis 
and assuming that the right optical quality has been obtained for the QDs that can be exploited for biological as well other electronic applications including optical sensor applications. Figure 1 shows UV-visible and photoluminescence spectrum of as-synthesized core-shell nanostructures for present use. The band gap based on absorption value is estimated to be about $2.78 \mathrm{eV}$ and that based on emission wavelength is $\sim 2.21 \mathrm{eV}$. The crystal structure and the particle diameter of the sample was studied by use of the powder XRD analysis which confirmed cubic crystal structure with diameter of about $4-5 \mathrm{~nm}$. The narrow peak width in emission spectrum indicated that the particles are uniformly distributed within a given solution. An average particle size of about 3 - 4 nm was observed from TEM.

\section{Cellular Uptake Induced Biotoxicity of CdS/CdSe}

Cytotoxicity was assessed by assigning the MTT assay on anti cancer cell lines. In our studies CdS/CdSe treated MCF-7, HEK-293 and EAC cells were fixed and visualized in a fluorescence microscope (Eclips 90i, Nikon) in Figure 2. The release of free cadmium has often been reported by researcher during the study of their biocytotoxicity e.g. King-Heiden et al. [25] have reported release of free Cd and Se from ZnS-capped CdSe QDs when tested on to the zebrafish embryo Daniorerio. It is opined that size dependent intracellular routing enables QDs to reach organelles that are otherwise inaccessible to metal ions. It has been proposed by Parak et al. [26] that QDs uptake by a cell is packaged into small intracellular vesicles and transported from the cell periphery to the perinuclear region. There is also a report that cadmium ions are predominantly located in the cytoplasm, where they are sequestered by metallothione [27].

The cytotoxicity response against CdS/CdSe QDs was shown by all the cell lines and it was found that the response was more in MCF-7 cell lines while incubated for 24 hours and 48 hours with $2.5 \mu \mathrm{g}, 5 \mu \mathrm{g}$ and $10 \mu \mathrm{g}$ concentration as compared to the other cell lines HEK-293 and EAC. Around $63.422 \%, 46.11 \%$ and $44.81 \%$
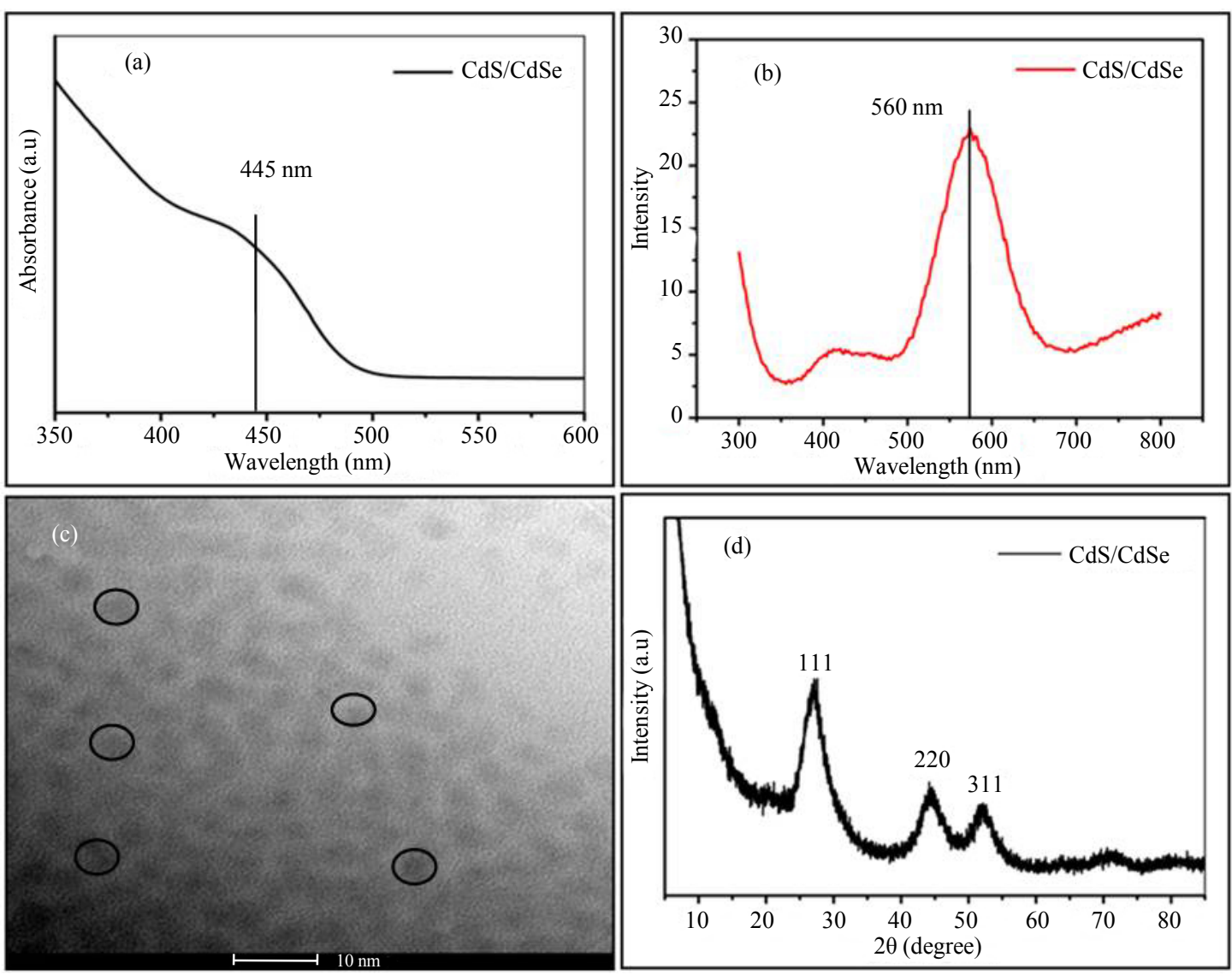

Figure 1. (a) UV-Visible absorption spectrum; (b) photoluminescence spectrum $\left(\lambda_{\mathrm{ex}}=350 \mathrm{~nm}\right)$; (c) TEM; (d) XRD of core-shell CdS/CdSe QDs. 


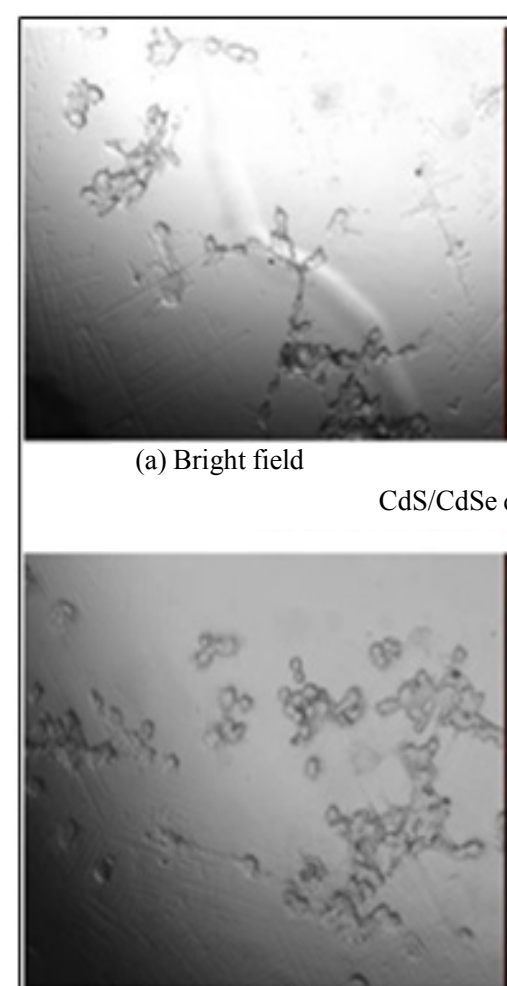

(a) Bright field

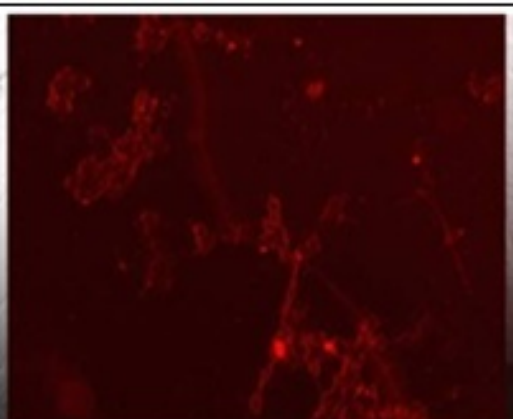

(b) Fluorescence

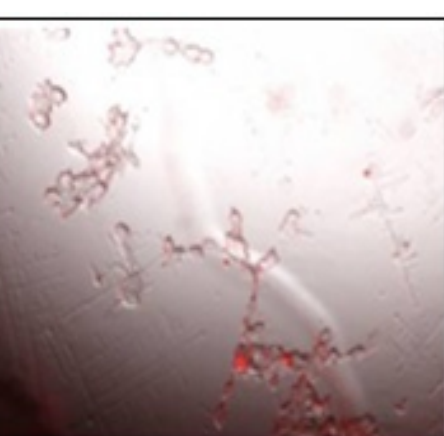

(c) Merged

$\mathrm{CdS} / \mathrm{CdSe}$ quantum dot cellular uptake in HEK-29 (20x)

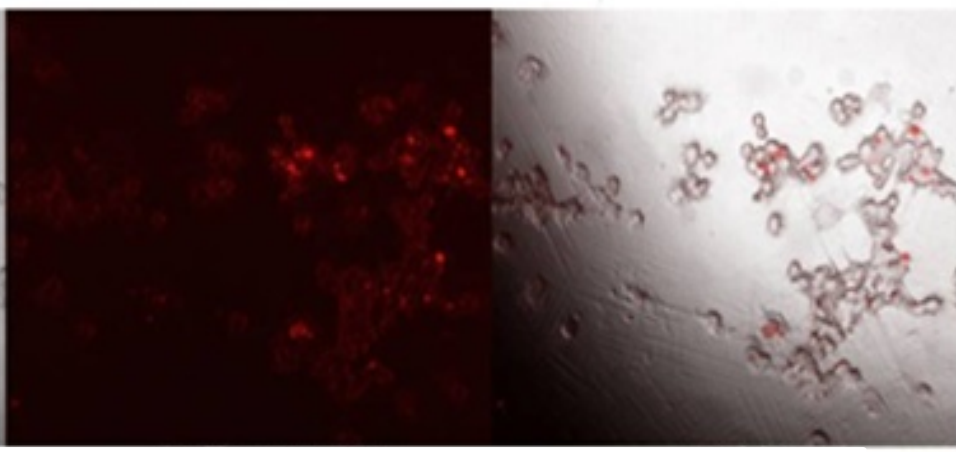

(b) Fluorescence

(c) Merged

CdS/CdSe quantum dot cellular uptake in MCF-7 (20x)

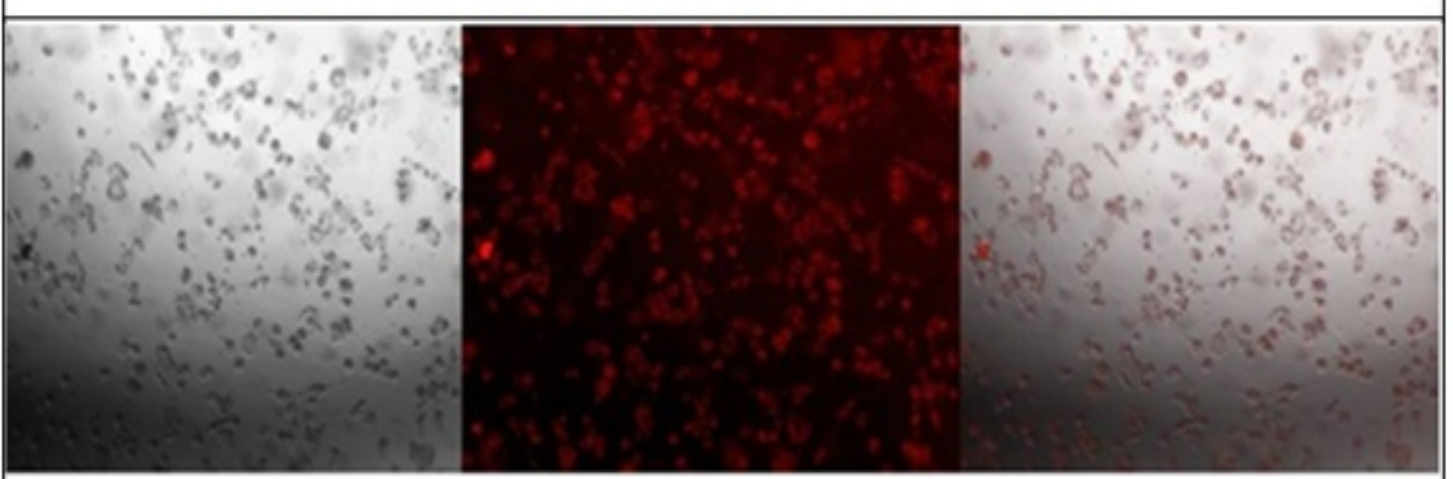

(a) Bright field

(b) Fluorescence

(c) Merged

$\mathrm{CdS} / \mathrm{CdSe}$ quantum dot cellular uptake in EAC (20x)

Figure 2. HEK-293, MCF-7 and EAC cells were treated with $10 \mu \mathrm{g} / \mathrm{ml}$ of CdS/CdSe quantum dots, incubated for $3 \mathrm{hrs}$, then fixed with $4 \%$ para-formaldehyde and viewed under microscope [Nikon 90i] at Magnification $20 \times$.

cytoyoxicity was observed subsequently in MCF-7, HEK-293 and EAC cell lines at a concentration of $10 \mu \mathrm{g}$ in 48 hours (Table 1). 20\% less toxicity was shown by EAC cell lines in 48 hrs. But only 14\% cytotoxicity was indicated in $24 \mathrm{hrs}$ in EAC cell lines. The observed biotoxicity towards hydrophobic core-shell CdS/CdSe QDs in all cell lines is shown in Figure 3.

Our experimental study shows the QDs are more cytotoxic in MCF-7 compared to HEK-293, and EAC cells. Time dependent cellular up take induced biotoxicitywas observed to bemaximum post 48 hrsofincubation with $10 \mu \mathrm{g}$ conentration in MCF-7 cell lines. After performing the experiments, we observed that cytotoxicity, cellular uptake, internalization are concentration and time dependent as shown in Figure 3. The cytotoxicity of QDs 
Table 1. Percentage of cytotoxicity of CdS/CdSe on cell lines.

\begin{tabular}{ccccccc}
\hline Sample & \multicolumn{5}{c}{ Cell lines } \\
\cline { 2 - 7 } CdS/CdSe & \multicolumn{2}{c}{ HEK-293 } & MCF-7 & \multicolumn{2}{c}{ EAC } \\
\hline Conc. & $24 \mathrm{~h}$ & $48 \mathrm{~h}$ & $24 \mathrm{~h}$ & $48 \mathrm{~h}$ & $24 \mathrm{~h}$ & $48 \mathrm{~h}$ \\
$10 \mu \mathrm{g} / \mathrm{ml}$ & 15.4595 & 46.1148 & 16.6317 & 63.4224 & 14.0830 & 44.8163 \\
$5 \mu \mathrm{g} / \mathrm{ml}$ & 6.6747 & 7.6486 & 9.874 & 39.7930 & 0.7658 & 9.8283 \\
$2.5 \mu \mathrm{g} / \mathrm{ml}$ & 3.6721 & 0.2637 & 3.2647 & 11.2726 & - & - \\
\hline
\end{tabular}

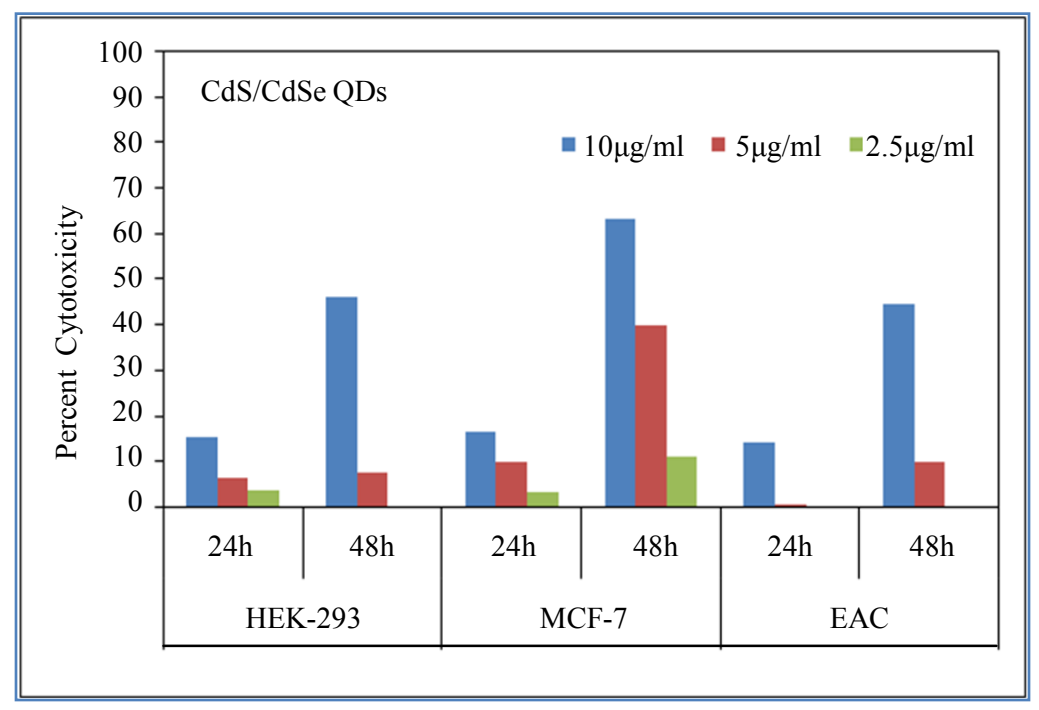

Figure 3. Time and dose dependent cytotoxicity of CdS/CdSe QDs in HEK-293, MCF-7 and EAC cell lines.

may be related to their physicochemical states as observed by Bruchez et al. [28]. The observed major QDs toxicity is directly proportional to the release of metal ions (e.g. $\mathrm{Cd}^{2+}$ ) which is in agreement with the earlier reports [29] [30]. However, according to some other reports, QDs are efficient energy donors and hence can be able to transfer energy to the oxygen molecules leading to the formation of reactive oxygen radicals/species which can promote cell death. The composition of the core and outer capping also plays vital role in QD toxicity. Thus formation of free radicals of the cadmium and selenium upon photo or air oxidation initiates the cytotoxicity [31] [32]. In the present case $\mathrm{CdS} / \mathrm{CdSe}$ nano-structure contains cadmium and therefore likely to increase cadmium radicals leading to the cytotoxicity.

\section{Conclusion}

$\mathrm{CdS} / \mathrm{CdSe}$ core-shell quantum dots were synthesized using 1,2,3-selenadiazole as selenium precursor and sogenerated QDs were studied for their bio-toxicity of three human cell lines viz HEK-293, MCF-7, EAC cells. Results confirm that QDs are toxic to all of them. The increase in concentration of QDs leads to higher toxicity response with time. The hydrophobic quantum dots were studied as they are less likely to disintegrate in biofluids present in the cells.

\section{Acknowledgements}

This work was supported by DIAT and Department of Science and Technology (DST), GOI program (SR/S1/PC-39/2010). SB and ASK thanks DIAT for fellowship. AT acknowledges UGC for her Junior Research Fellowship. 


\section{Conflict of Interest}

The authors declare no competing financial interest.

\section{References}

[1] Pan, Z.X., Zhang, H., Cheng, K., Hou, Y.M., Hua, J.L. and Zhong, X.H. (2012) Highly Efficient Inverted Type-I CdS/CdSe Core/Shell Structure QD-Sensitized Solar Cells. ACS Nano, 6, 3982-3991. http://dx.doi.org/10.1021/nn300278z

[2] Lee, Y.-L. and Lo, Y.-S. (2009) Highly Efficient Quantum-Dot-Sensitized Solar Cell Based on Co-Sensitization of CdS/CdSe. Advanced Functional Materials, 19, 604-609. http://dx.doi.org/10.1002/adfm.200800940

[3] Zhang, Q., Guo, X., Huang, X., Huang, S., Li, D., Luo, Y., Shen, Q., Toyoda, T. and Mengo, T. (2011) Highly Efficient CdS/CdSe-Sensitized Solar Cells Controlled by the Structural Properties of Compact Porous $\mathrm{TiO}_{2}$ Photoelectrodes. Physical Chemistry Chemical Physics, 13, 4659-4667. http://dx.doi.org/10.1039/c0cp02099k

[4] (a) Yu, X., Liao, J., Qiu, K., Kuang, D. and Su, C. (2011) Dynamic Study of Highly Efficient CdS/CdSe Quantum Dot-Sensitized Solar Cells Fabricated by Electrodeposition. ACS Nano, 5, 9494-9500. http://dx.doi.org/10.1021/nn203375g

(b) Yu, Z., Guo, L., Du, H., Krauss, T. and Silcox, J. (2005) Shell Distribution on Colloidal CdSe/ZnS Quantum Dots. Journal of Nano Letters, 5, 565-570. http://dx.doi.org/10.1021/n1048245n

[5] Zhao, M.X. and Zeng, E.Z. (2015) Application of Functional Quantum Dot Nanoparticles as Fluorescence Probes in Cell Labeling and Tumor Diagnostic Imaging. Nanoscale Research Letters, 10, 171. http://dx.doi.org/10.1186/s11671-015-0873-8

[6] Jiang, Z.J. and Kelley, D.F. (2013) Stranski-Krastanov Shell Growth in ZnTe/CdSe Core/Shell Nanocrystals. Journal of Physical Chemistry C, 117, 6826-6834. http://dx.doi.org/10.1021/jp4002753

[7] Gomes, A.O.S., Cecilia, S.V., Diogo, B.A., Jacenir, R., Santos-Mallet, F.S., Menna-Barreto, R., Carlos, L.C. and Feder, D. (2011) CdTe and CdSe Quantum Dots Cytotoxicity: A Comparative Study on Microorganisms. Sensors, 11, 11664-11678. http://dx.doi.org/10.3390/s111211664

[8] Shirin, G., Ramesh, B. and Seifalian, M.A. (2011) Fluorescence Nanoparticles "Quantum Dots” as Drug Delivery System and Their Toxicity: A Review. Journal of Drug Targeting, 19, 475-486. http://dx.doi.org/10.3109/1061186X.2010.526227

[9] Peddeti, S., Ithurria, S., Heuclin, H., Patriarxhe, G. and Dubertret, B. (2014) Type-II CdSe/CdTe Core/Crown Semiconductor Nanoplatelets. Journal of the American Chemical Society, 136, 16430-16438. http://dx.doi.org/10.1021/ja509307m

[10] Reiss, P., Bleuse, J. and Pron, A. (2002) Highly Luminescent CdSe/ZnSe Core/Shell Nanocrystals of Low Size Dispersion. Nano Letters, 2, 781-784. http://dx.doi.org/10.1021/n1025596y

[11] (a) Kim, S., Fisher, B., Eiseler, J. and Bawendi, M. (2003) Type-II Quantum Dots: CdTe/CdSe(Core/Shell) and CdSe/ $\mathrm{ZnTe}$ (Core/Shell) Heterostructures. Journal of the American Chemical Society, 125, 11466-11467.

http://dx.doi.org/10.1021/ja0361749

(b) Seo, H. and Kim, S.W. (2007) In Situ Synthesis of CdTe/CdSe Core-Shell Quantum Dots. Chemistry of Materials, 19, 2715-2717. http://dx.doi.org/10.1021/cm070209c

(c) Wang, J., Mora-Serio, I., Pan, Z., Zhao, K., Zhang, H., Feng, Y., Yang, G., Zhong, X. and Bisquert, J. (2013) Core/Shell Colloidal Quantum Dot Exciplex States for the Development of Highly Efficient Quantum-Dot-Sensitized Solar Cells. Journal of the American Chemical Society, 135, 15913-15922. http://dx.doi.org/10.1021/ja4079804

[12] (a) Bhanoth, S., More, P., Jadhav, A. and Khanna, P.K. (2014) Core-Shell ZnSe-CdSe Quantum Dots: A Facile Approach via Decomposition of Cyclohexeno-1,2,3-Selenadiazole. RSC Advances, 4, 17526-17532. http://dx.doi.org/10.1039/c4ra00676c

(b) Beri, R.K. and Khanna, P.K. (2011) “Green” Synthesis of Cadmium Selenide Nanocrystals: The Scope of 1,2,3-Selendiazoles in the Synthesis of Magic-Size Nanocrystals and Quantum Dots. Journal of Nanoscience and Nanotechnology, 11, 5137-5142. http://dx.doi.org/10.1166/jnn.2011.4143

(c) Beri, R.K., More, P., Bharate, B.G. and Khanna, P.K. (2010) Band-Gap Engineering of ZnSe Quantum Dots via a Non-TOP Green Synthesis by Use of Organometallic Selenium Compound. Current Applied Physics, 10, 553-556. http://dx.doi.org/10.1016/j.cap.2009.07.019

[13] Derfus, A.M., Chan, W.C. and Bhatia, S.N. (2004) Probing the Cytotoxicity of Semiconductor Quantum Dots. Nano Letters, 4, 11-18. http://dx.doi.org/10.1021/n10347334

[14] Pan, Y., Neuss, S., Leifert, A., Fischer, M., Wen, F., Simon, U., Schmid, G., Brandau, W. and Jahnen-Dechent, W. (2007) Size-Dependent Cytotoxicity of Gold Nanoparticles. Small, 3, 1941-1949. http://dx.doi.org/10.1002/smll.200700378 
[15] Dabbousi, B.O., Rodriguez-Viejo, J., Mikulec, F.V., Heine, J.R., Mattoussi, H., Ober, R., Jensen, K.F. and Bawendi, M.G. (1997) (CdSe)ZnS Core-Shell Quantum Dots: Synthesis and Characterization of a Size Series of Highly Luminescent Nanocrystallites. Journal of Physical Chemistry B, 101, 9463-9475. http://dx.doi.org/10.1021/jp971091y

[16] Selvan, S.T. (2010) Silica-Coated Quantum Dots and Magnetic Nanoparticles for Bioimaging Applications (Mini-Review). Biointerphases, 5, FA110-FA115. http://dx.doi.org/10.1116/1.3516492

[17] Dong, C., Kashan, M.L., Lowery, D., Dordick, J.S., Reynolds, S.H., Rojanasakul, Y., Sargent, L.M. and Dinu, C.Z. (2013) Exposure to Carbon Nanotubes Leads to Changes in the Cellular Biomechanics. Advanced Healthcare Materials, 2, 945-951. http://dx.doi.org/10.1002/adhm.201200430

[18] Dong, C., Eldawud, R., Sergent, L.M., Kasan, M.L., Lowery, D., Rojanasakul, Y. and Dinu, C.Z. (2014) Towards Elucidating the Effects of Purified MWCNTs on Human Lung Epithelial Cells. Environmental Science: Nano, 1, 595-603. http://dx.doi.org/10.1039/C4EN00102H

[19] Siegrist, K.J., Reynolds, S.H., Kashan, M.L., Lowry, D.T., Dong, C., Hubbs, A.F., Young, S.H., Salisbury, J.L., Porter, D.W., Benkovic, S.A., McCawley, M., Keane, M.J., Mostovich, J.T., Bunker, K.L., Cena, L.G., Sparrow, M.C., Sturgeon, J.L., Dinu, C.Z. and Sargent, L.M. (2014) Genotoxicity of Multi-Walled Carbon Nanotubes at Occupationally Relevant Doses. Particle and Fibre Toxicology, 11, 6. http://dx.doi.org/10.1186/1743-8977-11-6

[20] Zhang, H., Chen, Y., Liang, M., Xu, L., Qi, S., Chen, H. and Chen, X. (2014) Solid-Phase Synthesis of Highly Fluorescent Nitrogen-Doped Carbon Dots for Sensitive and Selective Probing Ferric Ions in Living Cells. Analytical Chemistry, 86, 9846-9852. http://dx.doi.org/10.1021/ac502446m

[21] Meier, H. and Voigt, E. (1972) Bildung und fragmentierung von cycloalkeno-1,2,3-selenadiazolen. Tetrahedron, 28, 187-198. http://dx.doi.org/10.1016/0040-4020(72)80068-1

[22] Verma, A.K. and Sachin, K. (2008) Novel Hydrophilic Drug Polymer Nano-Conjugates of Cisplatin Showing Long Blood Retention Profile-Its Release Kinetics, Cellular Uptake and Bio-Distribution. Current Drug Delivery, 5, 120126. http://dx.doi.org/10.2174/156720108783954806

[23] Verma, A.K., Sachin, K., Saxena, A. and Bohidar, H.B. (2005) Release Kinetics from Bio-Polymeric Nanoparticles Encapsulating Protein Synthesis Inhibitor-Cycloheximide, for Possible Therapeutic Applications. Current Pharmaceutical Biotechnology, 6, 121-130. http://dx.doi.org/10.2174/1389201053642349

[24] Kumar, P., Meena, R., Paulraj, R., Chanchal, A., Verma, A.K. and Bohidar, H.B. (2012) Fluorescence Behavior of Non-Functionalized Carbon Nanoparticles and Their in Vitro Applications in Imaging and Cytotoxic Analysis of Cancer Cells. Biointerfaces, 91, 34-40. http://dx.doi.org/10.1016/j.colsurfb.2011.10.034

[25] King-Heiden, T.C., Wiecinski, P.N., Mangham, A.N., Metz, K.M., Nesbit, D., Pedersen, J.A., Hameras, R.J., Heideman, W. and Peterson, R.E. (2009) Quantum Dot Nanotoxicity Assessment Using the Zebrafish Embryo. Environmental Science \& Technology Letters, 43, 1605-1611. http://dx.doi.org/10.1021/es801925c

[26] Parak, W.J., Boudreau, R., et al. (2002) Cell Motility and Metastatic Potential Studies Based on Quantum Dot Imaging of Phagokinetic Tracks. Advanced Materials, 14, 882-885. http://dx.doi.org/10.1002/1521-4095(20020618)14:12<882::AID-ADMA882>3.0.CO;2-Y

[27] Beyersmann, D. and Hechtenberg, S. (1997) Cadmium, Gene Regulation, and Cellular Signalling in Mammalian Cells. Toxicology and Applied Pharmacology, 144, 247-261. http://dx.doi.org/10.1006/taap.1997.8125

[28] Bruchez, M., Moronne, M., Gin, P., Weiss, S. and Alivisatos, A.P. (1998) Semiconductor Nanocrystals as Fluorescent Biological Labels. Science, 281, 2013-2016. http://dx.doi.org/10.1126/science.281.5385.2013

[29] Rikans, L.E. and Yamano, T.J. (2000) Mechanisms of Cadmium-Mediated Acute Hepatotoxicity. Journal of Biochemical and Molecular Toxicology, 14, 110-117. http://dx.doi.org/10.1002/(SICI)1099-0461(2000)14:2<110::AID-JBT7>3.0.CO;2-J

[30] Sanwlani, S., Rawat, K., Pal, M., Bohidar, H.B. and Verma, A.K. (2014) Cellular Uptake Induced Biotoxicity of Surface-Modified CdSe Quantum Dots. Journal of Nanoparticle Research, 16, 2382. http://dx.doi.org/10.1007/s11051-014-2382-6

[31] Yaghini, E., Seifalian, A.M. and MacRobert, A.J. (2009) Quantum Dots and Their Potential Biomedical Applications in Photosensitization for Photodynamic Therapy. Nanomedicine (London), 4, 353-363. http://dx.doi.org/10.2217/nnm.09.9

[32] Ipe, B.I., Lehnig, M. and Niemeyer, C.M. (2005) On the Generation of Free Radical Species from Quantum Dots. Small, 1, 706-709. http://dx.doi.org/10.1002/smll.200500105 